\title{
NAT2 AND ORAL CLEFTS: EVALUATION OF GENETIC RISK AND THE RELATIVE IMPORTANCE OF EMBRYO AND MATERNAL GENOTYPES
}

\author{
VARIANTES DE NAT2 Y FISURAS ORALES: EVALUACIÓN DEL RIESGO \\ GENÉTICO Y LA RELATIVA IMPORTANCIA DE LOS GENOTIPOS DEL \\ EMBRIÓN Y MATERNO
}

\author{
María Rita Santos ${ }^{1 *}$, Hebe Campaña ${ }^{2}$ Laura Smeldy Jurado Medina1 , Camila Sala1 , Marina \\ Muzzio1, Jorge Santiago López-Camelo² y Graciela Bailliet ${ }^{1}$

\begin{abstract}
${ }^{I}$ Instituto Multidisciplinario de Biología Celular (IMBICE). Comisión de Investigaciones Científicas de la Provincia de Buenos Aires (CICPBA). Consejo Nacional de Investigaciones Científicas y Técnicas (CONICET). Universidad Nacional de La Plata (UNLP). La Plata. Buenos Aires. Argentina
\end{abstract} \\ ${ }^{2}$ Centro de Educación Médica e Investigación Clínicas "Norberto Quirno" (CEMIC). CABA. Argentina
}

KEY WORDS N-acetiltransferase 2; cleft lip; cleft palate; ECLAMC

ABSTRACT Non-syndromic cleft lip with or without cleft palate (NSCLP) is a congenital malformation that shows the characteristics of a multifactorial pathology. In order to describe the genetic predisposition to this disorder, $N A T$ genes were analyzed with special interest since they codify for $\mathrm{N}$-acetyltransferases, the enzymes responsible for the biotransformation of arylamines, hydrazine drugs and a great number of toxins and carcinogens present in diet, cigarette smoke and the environment. The allelic transmission of
NAT2 that determines the slow acetylator phenotype in 174 trios (case-mother/father) from ECLAMC (Latin American Collaborative Study of Congenital Malformations) maternities in Argentina was evaluated. The *4, *5B, *6, and *7 variants by PCR-RFLP were analyzed. A higher risk for the $5 \mathrm{~B} * 5 \mathrm{~B} *$ genotypes $(\mathrm{OR}=2.24 ; p=0.050)$ was found, at the expense of the cases from Patagonia, without the influence of the maternal genotype. Rev Arg Antrop Biol 21(1), 2019. doi:10.17139/raab.2019.0021.01.08

\section{PALABRAS CLAVE N-acetiltransferasa 2; labio leporino; paladar hendido; ECLAMC}

RESUMEN El labio leporino con o sin paladar hendido (NSCLP) es una malformación congénita que presenta las características de una patología multifactorial. Se consideran de especial interés los genes NAT que codifican para las Nacetiltransferasas, enzimas responsables de la biotransformación de arilaminas, fármacos de hidrazina, y de un gran número de toxinas y carcinógenos presentes en la dieta, el humo de cigarro y el medio ambiente. Lo expuesto anteriormente ha despertado la sospecha de un posible rol de NAT2 en la manifestación de LL/PH en el recién nacido expuesto.
En este trabajo se ha evaluado la transmisión alélica de variantes que determinan el fenotipo acetilador lento en 174 tríos (caso, madre y/o padre) reclutados por el ECLAMC (Estudio Colaborativo Latinoamericano de Malformaciones Congénitas) en maternidades de Argentina. Se analizaron las variantes *4, *5B, *6y*7 mediante PCR-RFLP. Se halló un riesgo mayor en los casos con genotipos $5 \mathrm{~B} * 5 \mathrm{~B} *(\mathrm{OR}=2,24$; $p=0,050$ ), a expensas de los casos de Patagonia, sin influencia del genotipo materno. Rev Arg Antrop Biol 21(1), 2019. doi:10.17139/raab.2019.0021.01.08

tic and carcinogenic agents (Krajinovic, Richer, Sinnett, Labuda and Sinnett, 2000). This heteropalate is a congenital condition with multifactorial etiology (van Rooij et al., 2003). Its prevalence at birth is associated with environmental factors, geographical origin and socioeconomic conditions (Schutte and Murray, 1999). NAT2 is involved in xenobiotic detoxification and its genetic expression is induced as the response to these compounds. Thus, a change in the genetic level that affects the activity or expression of a gene or protein involved in the metabolism of these substances can increase the risk of the disease. Humans can be classified as fast or slow acetylators based on hereditary differences in the speed of $\mathrm{N}$-acetylation of therapeu-

\begin{abstract}
*Correspondencia a: María Rita Santos. Instituto Multidisciplinario de Biología Celular (IMBICE). Comisión de Investigaciones Científicas de la Provincia de Buenos Aires (CICPBA). Consejo Nacional de Investigaciones Científicas y Técnicas (CONICET). Universidad Nacional de La Plata (UNLP). Calle 526 entre 10 y 11 s/n. 1900 La Plata. Buenos Aires. Argentina. Email: mritasantos@yahoo.com.ar
\end{abstract}

Financiamiento: PIP 2013-2015 No 325 otorgado a la Dra. Graciela Bailliet.

Recibido 15 Enero 2018; aceptado 14 Junio 2018

doi:10.17139/raab.2019.0021.01.08 
geneity in $\mathrm{N}$-acetyltransferase enzyme activation is called acetylation polymorphism and is one of the most common hereditary variations that affect xenobiotic metabolism. The aim of this work was to assess the connection between NAT2 genotypes for the slow acetylator phenotype and the risk of oral clefts.

Poletta, Castilla, Orioli and López-Camelo (2007) described unequal birth prevalence rate (BPR) among different geographic areas in South America through the analysis of 5128 NSCLP cases and 3712 controls, over 4199630 consecutive births occurred between 1967 and 2004 in ECLAMC maternity hospitals (Castilla and Orioli, 1983). Expected values were cleft BPRs registered for the entire ECLAMC hospital network. Seven clusters for NSCLP cases of high BPR were identified. These clusters were associated with high altitude above sea level, Amerindian ancestry, and low socioeconomic strata. This work series of samples gathered two out of seven regions with high BPR for NSCLP, Northwest and Patagonia, in Argentina.

A family-based design, with trios of case and parents (TCP) as an adequate method to assess genotype-disease association in order to minimize the population structure effect of the sample was applied.

\section{MATERIALS AND METHODS}

The cases selected showed NSCLP as their only anomaly. Exclusion criteria were syndromic cases, stillborn, and both syndromic and nonsyndromic cases born with cleft palate only. The sample consisted of 97 complete (case, mother and father) and 77 incomplete (case-mother; casefather) trios selected from individuals from ECLAMC Argentine maternities (Table 1) between 2003 and 2006. The Project was approved by the CEMIC Ethics Counseling Committee. Molecular analysis of $* 4$ (reference allele), $* 5 \mathrm{~B}(481 \mathrm{C}>\mathrm{T}$, rs1799929), *6 (590G >A, rs1799930), and *7 $(857 \mathrm{G}>\mathrm{A}, \mathrm{rs} 1799931)$ alleles and their identification were performed following a previously described protocol (Santos, Ramallo, Muzzio, López Camelo and Bailliet, 2015).

In the first place, the effect of alleles as a whole, and after that, the effect of each allele in particular were analyzed. The two populations showing high BPR for NSCLP, Tucumán (13.0/10.000 births;
$95 \% \mathrm{CI}=12.5$ - 15.7$)$ and Patagonia $(15.6 / 10.000$ births; $95 \% \mathrm{CI}=14.9$ - 18.6), were analyzed together ("Tucumán + Patagonia") and independently ("Tucumán" and "Patagonia"). All maternities with expected BPR (10.8/10.000 births; 95\% $\mathrm{CI}=10.4-11.1)$ values indistinguishable from the entire ECLAMC hospital network were called "Rest" (Poletta et al., 2007). Category "All" represents the total number of maternity hospitals analyzed.

In order to assess genotype and studied malformation association, a log-linear method for analysis of case-parent-triad data, based on maximum likelihood with stratification on parental mating type were used (Weinberg, 1999). The method leads to estimates of association parameters, such as relative risks, for a single allele, and also to likelihood ratio $\mathrm{Chi}^{2}$ tests of linkage disequilibrium. Hardy-Weinberg equilibrium need not be assumed. The method generalizes easily to accommodate maternal effects on risk and, in fact, produces powerful and orthogonal tests of the contribution of fetal versus maternal genetic factors. Model: $\log (\mathrm{Y})=\mathrm{aM}+$ $\mathrm{bF}+\sum \mathrm{ciPM}$, where a estimate maternal effect, $\mathrm{b}$ fetal effect and $\mathrm{c}$ estimate 6 parental mating type effects.

\section{RESULTS}

Allelic and genotypic frequencies and Hardy-Weinberg equilibrium were previously shown in Santos et al. (2015). Table 2 shows risk alleles $* 5 \mathrm{~B}+* 6+* 7$ compared with the reference allele $* 4$. Tables 3 , 4, and 5 shows risk alleles $* 5 \mathrm{~B}, * 6$ and $* 7$ respectively. Genotypes of cases carrying two alleles with low metabolic rate showed risk in "All" category $(\mathrm{OR}=2.12 ; p=0.049)$. Risk was observed in categories "Patagonia" $(\mathrm{OR}=3.60 ; p=0.042)$ and "Tucumán + Patagonia" $(\mathrm{OR}=4.37 ; p=0.005)$ too. No risk was detected for "Rest" category (Table 2).

Cases included in "All" category showed significant risk for heterozygous $(\mathrm{OR}=1.61$; $p=0.038)$ and homozygous genotypes $(\mathrm{OR}=2.24 ; p=0.050)$ for $* 5 \mathrm{~B}$ allele. For "Patagonia", significant risk was observed for heterozygous $(\mathrm{OR}=2.44 ; p=0.037)$ and homozygous genotypes $(\mathrm{OR}=5.98 ; p=0.044)$ for *5 allele (Table 3 ). 
NAT2 AND ORAL CLEFTS

TABLE 1. Complete and incomplete trios from ECLAMC maternities

\begin{tabular}{cccccc}
\hline Hospital & Region & City & Trios & Incomplete trios & Complete trios \\
\hline 318 & Metropolitan & Buenos Aires & 36 & 11 & 25 \\
322 & Metropolitan & Buenos Aires & 3 & 3 & 0 \\
325 & Metropolitan & Lomas de Zamora & 2 & 1 & 1 \\
332 & Metropolitan & Lanús Este & 3 & 2 & 1 \\
413 & Pampa & Rosario & 16 & 4 & 12 \\
416 & Pampa & La Plata & 4 & 1 & 3 \\
418 & Patagonia & Bahía Blanca & 9 & 5 & 4 \\
614 & Cuyo & San Luis & 5 & 4 & 1 \\
803 & Northwest & S.M de Tucumám & 37 & 14 & 23 \\
906 & Patagonia & Esquel & 5 & 3 & 2 \\
907 & Patagonia & El Bolsón & 33 & 18 & 15 \\
909 & Patagonia & Bariloche & 21 & 11 & 10 \\
\hline Total & & & 77 & 97 \\
\hline
\end{tabular}

S.M.: San Miguel.

TABLE 2. Risk evaluation of maternal and case genotypes of 174 trios, through a linear regression model (alleles $* 5 B+* 6+* 7$ )

\begin{tabular}{|c|c|c|c|c|c|c|c|c|c|c|}
\hline \multirow[t]{2}{*}{ Maternities } & \multirow[t]{2}{*}{$\mathrm{n}$} & \multirow[t]{2}{*}{ Genotype } & \multicolumn{4}{|c|}{ Mother } & \multicolumn{4}{|c|}{ Case } \\
\hline & & & OR & $95 \%$ & $\mathrm{z}$ & $\mathrm{p}$ & OR & $95 \%$ & $\mathrm{z}$ & $\mathrm{p}$ \\
\hline \multirow[t]{2}{*}{ All } & 174 & $4 / 5 \mathrm{~B} 67^{*}$ & 0,74 & $0,37-1,49$ & $-0,83$ & 0,406 & 1,51 & $0,79-2,88$ & 1,25 & 0,211 \\
\hline & & $5 \mathrm{~B} 67 / 5 \mathrm{~B} 67 * *$ & 0,96 & $0,49-1,87$ & $-0,12$ & 0,904 & 2,12 & $1,01-4,46$ & 1,96 & 0,049 \\
\hline \multirow{2}{*}{$\begin{array}{c}\text { Tucumán + } \\
\text { Patagonia }\end{array}$} & 96 & $4 / 5 \mathrm{~B} 67^{*}$ & 1,30 & $0,59-2,89$ & 0,65 & 0,516 & 1,70 & $0,77-3,74$ & 1,32 & 0,188 \\
\hline & & $5 \mathrm{~B} 67 / 5 \mathrm{~B} 67 * *$ & 1,65 & $0,71-3,83$ & 1,17 & 0,242 & 4,37 & $1,55-12,35$ & 2,78 & 0,005 \\
\hline \multirow[t]{2}{*}{ Tucumán } & 37 & $4 / 5 \mathrm{~B} 67^{*}$ & 3,97 & $0,83-19,03$ & 1,73 & 0,084 & 2,18 & $0,41-11,50$ & 0,92 & 0,359 \\
\hline & & $5 \mathrm{~B} 67 / 5 \mathrm{~B} 67 * *$ & 1,77 & $0,50-6,19$ & 0,9 & 0,368 & 6,55 & $0,92-46,52$ & 1,88 & 0,060 \\
\hline \multirow[t]{2}{*}{ Patagonia } & 59 & 4/5B $67 *$ & 0,80 & $0,29-2,23$ & $-0,42$ & 0,674 & 1,60 & $0,66-3,89$ & 1,04 & 0,299 \\
\hline & & $5 \mathrm{~B} 67 / 5 \mathrm{~B} 67 * *$ & 1,97 & $0,55-7,06$ & 1,04 & 0,298 & 3,60 & $1,05-12,41$ & 2,03 & 0,042 \\
\hline \multirow[t]{2}{*}{ Rest } & 78 & $4 / 5 \mathrm{~B} 67 *$ & 0,27 & $0,06-0,85$ & $-1,75$ & 0,08 & 1,03 & $0,33-3,14$ & 0,05 & 0,963 \\
\hline & & $5 \mathrm{~B} 67 / 5 \mathrm{~B} 67 * *$ & 0,38 & $0,35-1,44$ & $-1,43$ & 0,153 & 1,06 & $0,32-3,57$ & 0,10 & 0,918 \\
\hline
\end{tabular}

*: Genotypes 45B, 46, and 47; **: Genotypes 5B5B, 5B6, 5B7, 66, 67, and 77; All: all maternities (803, 906, 907, 909, 325, 322, 332, 413, 416, 418, 614); Tucumán + Patagonia:803, 906, 907, 909; Tucumán:803; Patagonia:906, 907, 909; Rest:318, $322,325,332,413,416,418,614$; n:number of trios. 
TABLE 3. Assessment of maternal and case risk genotypes in 174 trios, through a linear regression model (risk allele: $* 5 B)$

\begin{tabular}{|c|c|c|c|c|c|c|c|c|c|c|}
\hline \multirow[t]{2}{*}{ Maternities } & \multirow[t]{2}{*}{$\mathrm{n}$} & \multirow[t]{2}{*}{ Genotype } & \multicolumn{4}{|c|}{ Mother } & \multicolumn{4}{|c|}{ Case } \\
\hline & & & OR & $95 \%$ & $\mathrm{z}$ & $\mathrm{p}$ & OR & $95 \%$ & $\mathrm{z}$ & $\mathrm{p}$ \\
\hline \multirow[t]{2}{*}{ All } & \multirow[t]{2}{*}{174} & $5 \mathrm{~B} / 467 *$ & 0,97 & $0,61-1,22$ & $-0,13$ & 0,896 & 1,61 & $1,02-2,54$ & 2,07 & 0,038 \\
\hline & & $5 \mathrm{~B} 5 \mathrm{~B}$ & 1,58 & $0,65-3,86$ & 1,00 & 0,317 & 2,24 & $1,00-5,01$ & 1,95 & 0,050 \\
\hline \multirow{2}{*}{$\begin{array}{c}\text { Tucumán + } \\
\text { Patagonia }\end{array}$} & \multirow[t]{2}{*}{96} & $5 B / 467 *$ & 1,16 & $0,63-2,15$ & 0,48 & 0,632 & 1,53 & $0,85-2,75$ & 1,44 & 0,151 \\
\hline & & $5 \mathrm{~B} 5 \mathrm{~B}$ & 3,47 & $0,42-28,67$ & 1,15 & 0,248 & 2,91 & $0,85-9,94$ & 1,7 & 0,088 \\
\hline \multirow[t]{2}{*}{ Tucumán } & \multirow[t]{2}{*}{37} & $5 \mathrm{~B} / 467 *$ & 2,21 & $0,64-2,21$ & 1,26 & 0,208 & 0,75 & $0,29-1,93$ & $-0,59$ & 0,555 \\
\hline & & $5 \mathrm{~B} 5 \mathrm{~B}$ & 0,29 & $0,03-3,13$ & 1,02 & 0,309 & 1,23 & $0,19-7,94$ & 0,22 & 0,824 \\
\hline \multirow[t]{2}{*}{ Patagonia } & \multirow[t]{2}{*}{59} & $5 B / 467 *$ & 1,08 & $0,46-2,23$ & 0,02 & 0,984 & 2,44 & $1,06-5,57$ & 2,09 & 0,037 \\
\hline & & $5 \mathrm{~B} 5 \mathrm{~B}$ & ---- & ----- & ----- & ----- & 5,98 & $1,06-33,71$ & 2,01 & 0,044 \\
\hline \multirow[t]{2}{*}{ Rest } & \multirow[t]{2}{*}{78} & $5 B / 467 *$ & 0,81 & $0,38-1,72$ & $-0,55$ & 0,582 & 1,62 & $0,78-3,35$ & 1,3 & 0,194 \\
\hline & & $5 \mathrm{~B} 5 \mathrm{~B}$ & 1,02 & $0,34-2,98$ & 0,01 & 0,990 & 2,10 & $0,69-6,41$ & 1,3 & 0,194 \\
\hline
\end{tabular}

*:Genotypes 45B, 46, and 47; All:all maternities (803, 906, 907, 909, 325, 322, 332, 413, 416, 418, 614); Tucumán + Patagonia:803, 906, 907, 909; Tucumán:803; Patagonia:906, 907, 909; Rest:318, 322, 325, 332, 413, 416, 418, 614; n:number of trios; ----: lack of convergence in the estimate.

The analysis of allele *6 did not show risk + Patagonia" cases $(\mathrm{OR}=2.32 ; p=0.039)$ (Table genotypes in any of the categories studied (Ta- 5). Homozygous genotype risk for "Tucumán ble 4).

For allele *7 higher risk for the hetero+ Patagonia" was estimated from "Patagonia" due to the absence of mutated homozygote in zygous genotype was found only for “Tucumán “Tucumán” samples.

TABLE 4. Risk assessment of genotypes carrying risk allele *6 in mothers and cases, through linear regression.

\begin{tabular}{|c|c|c|c|c|c|c|c|c|c|c|}
\hline \multirow[t]{2}{*}{ Maternities } & \multirow[t]{2}{*}{$\mathrm{n}$} & \multirow[t]{2}{*}{ Genotype } & \multicolumn{4}{|c|}{ Mother } & \multicolumn{4}{|c|}{ Case } \\
\hline & & & OR & $95 \%$ & $\mathrm{z}$ & $\mathrm{p}$ & OR & $95 \%$ & $\mathrm{z}$ & $\mathrm{p}$ \\
\hline \multirow[t]{2}{*}{ All } & 174 & $6 / 45 \mathrm{~B} 7 *$ & 1,01 & $0,60-1,71$ & 0,05 & 0,959 & 0,96 & $0,57-1,60$ & $-0,16$ & 0,870 \\
\hline & & 66 & 0,79 & $0,20-3,18$ & $-0,33$ & 0,739 & 0,36 & $0,06-2,04$ & $-1,15$ & 0,250 \\
\hline \multirow[t]{2}{*}{ Tucumán +Patagonia } & 96 & $6 / 45 \mathrm{~B} 7 *$ & 1,28 & $0,70-2,34$ & 0,79 & 0,427 & 0,97 & $0,53-1,79$ & $-0,08$ & 0,935 \\
\hline & & 66 & 0,86 & $0,12-6,14$ & $-0,15$ & 0,878 & 0,65 & $0,04-11,49$ & $-0,29$ & 0,771 \\
\hline \multirow[t]{2}{*}{ Tucumán } & 37 & $6 / 45 \mathrm{~B} 7 *$ & 1,22 & $0,50-3,00$ & 0,44 & 0,657 & 1,48 & $0,59-3,71$ & 0,84 & 0,401 \\
\hline & & 66 & ----- & ----- & ---- & ---- & ----- & ----- & ----- & ----- \\
\hline \multirow[t]{2}{*}{ Patagonia } & 56 & $6 / 45 \mathrm{~B} 7^{*}$ & 1,22 & $0,54-2,77$ & 0,48 & 0,63 & 0,70 & $0,31-1,62$ & $-0,82$ & 0,410 \\
\hline & & 66 & 0,44 & $0,04-5,04$ & $-0,66$ & 0,507 & 0,49 & $0,03-9,11$ & $-0,48$ & 0,631 \\
\hline \multirow[t]{2}{*}{ Rest } & 78 & $6 / 45 \mathrm{~B} 7 *$ & 0,60 & $0,21-1,70$ & $-0,96$ & 0,335 & 1.00 & $0,39-2,53$ & 0,003 & 0,997 \\
\hline & & 66 & 0,67 & $0,05-10,64$ & $-0,26$ & 0,797 & ----- & ----- & ----- & ---- \\
\hline
\end{tabular}

*:Genotypes 46, 5B6, and 67; All:803, 906, 907, 909, 325, 322, 332, 413, 416, 418, 614; Tucumán + Patagonia:803, 906, 907, 909; Tucumán:803; Patagonia:906, 907, 909; Rest:318, 322, 325, 332, 413, 416, 418, 614; n:number of trios; ----: lack of convergence. 
TABLE 5. Risk assessment of genotypes carrying risk allele $* 7$ in mothers and cases, through linear regression

\begin{tabular}{|c|c|c|c|c|c|c|c|c|c|c|}
\hline \multirow[t]{2}{*}{ Maternities } & \multirow[t]{2}{*}{$\mathrm{n}$} & \multirow[t]{2}{*}{ Genotype } & \multicolumn{4}{|c|}{ Mother } & \multicolumn{4}{|c|}{ Case } \\
\hline & & & OR & $95 \%$ & $\mathrm{Z}$ & $\mathrm{p}$ & OR & $95 \%$ & $\mathrm{z}$ & $\mathrm{p}$ \\
\hline \multirow[t]{2}{*}{ All } & 174 & $7 / 45 B 6^{*}$ & 0,78 & $0,47-1,31$ & $-0,94$ & 0,348 & 1,06 & $0,66-1,70$ & 0,24 & 0,811 \\
\hline & & 77 & 0,88 & $0,19-3,96$ & $-0,17$ & 0,865 & 0,30 & $0,06-1,54$ & $-1,44$ & 0,148 \\
\hline \multirow[t]{2}{*}{ Tucumán + Patagonia } & 96 & $7 / 45 B 6 *$ & 0,85 & $0,41-1,77$ & $-0,44$ & 0,663 & 2,32 & $1,04-5,15$ & 2,07 & 0,039 \\
\hline & & 77 & 1,28 & $0,41-1,77$ & 0,20 & 0,842 & 2,19 & $0,12-40,32$ & 0,53 & 0,598 \\
\hline \multirow[t]{2}{*}{ Tucumán } & 37 & $7 / 45 B 6^{*}$ & 1,13 & $0,34-3,75$ & 0,21 & 0,837 & 2,87 & $0,81-10,31$ & 1,63 & 0,104 \\
\hline & & 77 & 0,83 & $0,05-12,83$ & $-0,14$ & 0,89 & ---- & ----- & ----- & ---- \\
\hline \multirow[t]{2}{*}{ Patagonia } & 56 & $7 / 45 B 6^{*}$ & 0,79 & $0,31-2,00$ & $-0,5$ & 0,615 & 2,10 & $0,76-5,79$ & 1,43 & 0,153 \\
\hline & & 77 & ----- & ----- & ----- & ----- & 2,19 & $0,12-40,32$ & 0,53 & 0,598 \\
\hline \multirow[t]{2}{*}{ Rest } & 78 & $7 / 45 B 6^{*}$ & 0,77 & $0,37-1,61$ & $-0,69$ & 0,493 & 0,61 & $0,32-1,18$ & $-1,48$ & 0,139 \\
\hline & & 77 & 0,82 & $0,10-5,75$ & $-0,26$ & 0,796 & 0,14 & $0,01-1,43$ & $-1,65$ & 0,098 \\
\hline
\end{tabular}

*:Genotypes 74, 75B, and 76; All:803, 906, 907, 909, 325, 322, 332, 413, 416, 418, 614; Tucumán + Patagonia:803, 906, 907, 909; Tucumán:803; Patagonia:906, 907, 909; Rest:318, 322, 325, 332, 413, 416, 418, 614; n:number of trios; ----:lack of convergence.

This linear regression model also allows calculating the risk from maternal genotypes. Analyzing the whole "All" sample, and also when considering the maternities of the smaller groups of "Tucumán", "Patagonia", "Tucumán + Patagonia", and "Rest", no maternal effect was found for any of the variables studied, neither pooled nor individually (Tables 2-5).

\section{DISCUSSION}

It is known that controls for a genetic study must be selected from the same genetic pool. The strategy of this paper was to recruit trios and dyads (case and parents) and use the genotypic information of the untransmitted chromosome of the parents as control, so as to reduce false positive bias due to population structure, adjusting for ancestry through design.

Maternities were classified according to geographic clusters detected by Poletta et al. (2007), who identified two geographic areas in Argentina with high prevalence of NSCLP at birth: North West and Patagonia. This grouping allows assuming that, through a parsimony principle, the anomaly is the result of a sole causal factor that compromises the cluster specifically.

To assess the association between presence of NSCLP and genotypes that determine the slow acetylator phenotype, variants $* 5 \mathrm{~B}, * 6$, and $* 7$ were considered, combining trios from all maternities in detriment of genetic homogeneity. For the whole sample, a significant risk was found, twice higher for NSCLP when the fetal genotype was homozygous for the risk alleles. Particularly, significant risk for "Tucumán" and "Patagonia" cases for genotypes with 2 risk alleles was found. "Tucumán" showed the highest risk but no statistical difference, probably due to the low number of trios in that region (type $\beta$ error) (Table 2).

The risk of allelic variants $* 5 \mathrm{~B}, * 6$, and $* 7$ individually was evaluated. Allele *5B showed association for the "All" category (heterozygotes, $\mathrm{OR}=1.61 ; p=0.038$; and homozygotes, $\mathrm{OR}=2.24 ; \quad p=0.050)$, and for "Patagonia" (heterozygotes, $\mathrm{OR}=2.44 ; p=0.037$; and homozygotes $\mathrm{OR}=5.98 ; p=0.044$ ), thus "Patagonia" is responsible for the increased risk in the "All" group. No association was observed between NSCLP and allele *6. Regarding variant $* 7$, a risk for heterozygous genotypes $(\mathrm{OR}=2.32$; 
$p=0.039$ ) was found only in "Tucumán $+\mathrm{Pa}$ tagonia" group. So, variants $* 5 \mathrm{~B}$ and $* 7$ but not $* 6$ are responsible for the estimated risk for SNPs *5B+*6+*7 among "All” (Table 2). In "Patagonia" cases, *5B allele is responsible for the risk, while in "Tucumán" *7 is.

Several studies have reported a correlation between high frequency of slow aceltylators in human populations practising subsistence farming, which suggests that a slower rate of acetylation may have gained selective advantage in populations shifting from foraging to agriculture during the Neolithic period. The same was observed for American hunter-gathering populations in which $N A T 2 * 4$ was predominant and $N A T 2 * 5 \mathrm{~B}$ and $N A T 2 * 7 \mathrm{~B}$ tended to be higher for agricultural populations (Luca et al., 2008; Sabbagh, Darlu, Crouau-Roy and Poloni, 2010). This is the case of the Northwest in the present work, region that has been occupied by agricultural populations since 8000 years BP, while Patagonia inhabitants displayed huntergathering subsistence strategies until the arrival of Europeans in Argentina. While NAT2*4 was predominant in Patagonian populations with frequencies of $40 \%$ or more, in the Northwest it was $30 \%$. For the rest of the hospital cases, the effect of migration could have probably produced intermediate frequencies of each genetic variation (Santos et al., 2015, present work). These genetic backgrounds would be responsible for the differentiation between the two areas with high birth rate prevalence, Northwest and Patagonia.

The linear regression model also allows inferring the relative importance of maternal genotypes in the causality of the anomaly studied. Using this test, no maternal effect could be detected for any of the variants analyzed, neither individually nor pooled. Moreover, Lie et al. (2008) did not find maternal effect in a sample of 314 trios from Norway $(\mathrm{OR}=1.00$; $\mathrm{IC}=0.5$ 1.8). Interestingly, Shi et al. (2007) showed a $20 \%$ higher risk of anomaly when the mother carried a risk allele $(p=0.03)$.

Other association studies on the same allelic variants and NSCLP are discordant (Birnbaum et al., 2009; Lammer, Iovannisci, Van Waes and Finnell, 2004; Lie et al., 2008; Marazita et al., 2004; Shi et al., 2007). Using the same Patagonia sample population as the one in the present work, from a complex segregation study Poletta (2010) suggested that the effect of the main gene for NSCLP could be modified by another locus and/or factor of environmental exposure. This main dominant gene would have low penetrance (6 to $15 \%$ ) and the frequency of the risk allele would be between 1 and $9 \%$, added to a multifactorial component (or residual variance unexplained by the main gene). Another finding, relevant to the interpretation of our results and key in the study of NSCLP, was the contribution of IRF6 to NSCLP (Zucchero et al., 2004). Authors analyzed 8003 individuals from 1,968 families from Asian, European and American populations. This work showed that all genes that contribute to the anomaly have a very low effect compared to IRF6's in NSCLP. Regarding segregation studies, evidence reported by Poletta (2010) and Zuchero et al. (2004) demonstrated that NAT2 is neither a necessary nor sufficient factor for NSCLP. Nevertheless, some involvement in cleft occurrence due their metabolizing function cannot be ruled out as part of this multifactorial component or residual variance unexplained by the main gene. Clearly, the high proportion of NSCLP cases is a result of other etiological agents, unassociated to these alleles.

\section{CONCLUSION}

The present work, through a family-based case-control design, confirms the association between the allele $* 5 \mathrm{~B}$, that determines the slow acetylator phenotype, and the occurrence of the NSCLP. This allelic variant could act as a marker in linkage disequilibrium of causal haplotypes. As markers, some NAT2 SNPs could be more informative in some human populations than in others and this could explain some discrepancies in the association results. Likewise, no participation of NAT2 can be disregarded in the generation of NSCLP as part of the multivariate component or residual variance not explained by the main gene.

\section{LITERATURE CITED}

Birnbaum, S., Ludwig, K.U., Reutter, H., Herms, S., Steffens, M., Rubini, .. . Mangold, M. (2009). Key susceptibility locus for nonsyndromic cleft lip with or without cleft palate on chromosome 8q24. Nature Genetics, 41, 473-477. doi: 10.1038/ng.333 
Castilla, E. E. and Orioli, I. M. (1983). El estudio colaborativo latinoamericano de malformaciones congénitas: ECLAMC/MONITOR. Interciencia, 8, 271-278.

Kiyohara, C., Otsu, A., Shirakawa, T., Fukuda, S. and Hopkin, J.M. (2002). Genetic polymorphisms and lung cancer susceptibility: a review. Lung Cancer, 37(3), 241-256.

Krajinovic, M., Richer, C., Sinnett, H., Labuda, D. and Sinnett, D. (2000). Genetic polymorphisms of N-acetyltransferases 1 and 2 and gene-gene interaction in the susceptibility to childhood acute lymphoblastic leukemia. Cancer Epidemiology, Biomarkers and Prevention, 9(6), 557-562.

Lammer, E. J., Sha, G. M., Iovannisci, D. M., Van Waes, J. and Finnell, R. H. (2004). Maternal smoking and the risk of orofacial clefts: susceptibility with NAT1 and NAT2 polymorphisms. Epidemiology, 15(2), 150-156. doi:10.1016/S0169-5002(02)00107-1

Lie, R. T., Wilcox, A. J., Taylor, J., Gjessing, H. K., Saugstad, O. D., Aabyholm, F. and Vindenes, H. (2008). Maternal smoking and oral clefts: the role of detoxification pathway genes. Epidemiology, 19(4), 606-615. doi:10.1097/EDE.0b013e3181690731

Luca, F., Bubba, G., Basile, M., Brdicka, R., Michalodimitrakis, E., Rickards, O., Vershubsky, G., QuintanaMurci, L., Kozlov, A.I. and Novelletto, A. (2008). Multiple advantageous amino acid variants in the NAT2 gene in human populations. PLoS ONE, 3(9), e3136. doi:10.1371/journal.pone.0003136

Marazita, M. L., Murray, J. C., Lidral, A. C., Arcos-Burgos, M., Cooper, M. E., Goldstein, T., . . . and Roddick, L. (2004). Meta-analysis of 13 genome scans reveals multiple cleft lip/palate genes with novel loci on 9q21 and 2q32-35. American Journal of Human Genetics, 75(2), 161-173. doi:10.1086/422475

Poletta, F. A. (2010). Epidemiología genética de fisuras orales en Sudamérica: estudio de Patagonia como área endémica. (Tesis de Doctorado). Facultad de Medicina, Universidad de Buenos Aires. Ciudad Autónoma de Buenos Aires.

Poletta, F. A., Castilla, E. E., Orioli, I. M. and López-Camelo,
J. S. (2007). Regional analysis on the occurrence of oral clefts in South America. American Journal of Medical Genetics A 143A(24), 3216-3227. doi:10.1002/ ajmg.a.32076

Sabbagh, A., Darlu, P., Crouau-Roy, B. and Poloni, E. S. (2011). Arylamine N-acetyltransferase 2 (NAT2) genetic diversity and traditional subsistence: a worldwide. Population survey. PLoS ONE 6(4), e18507. doi:10.1371/journal.pone.0018507

Santos, M. R., Ramallo, V., Muzzio, M., López Camelo, J. S. and Bailliet, G. (2015). Asociación entre polimorfismos del gen NAT2 y fisura labiopalatina no sindrómica en Argentina. Revista Médica de Chile, 143(4), 444450. doi:10.4067/S0034-98872015000400005

Shi, M., Christensen, K., Weinberg, C. R., Romitti, P., Bathum, L., Lozada, A., Morris, R. W., Lovett, M. and Murray, J.C. (2007). Orofacial cleft risk is increased with maternal smoking and specific detoxification-gene variants. American Journal of Human Genetics, 80(1), 76-90. doi:10.1086/510518

Schutte, B. C. and Murray, J. C. (1999). The many faces and factors of orofacial clefts. Human Molecular Genetics, 8(10), 1853-1859. doi:10.1093/hmg/8.10.1853

van Rooij, I. A., Vermeij-Keers, C., Kluijtmans, L. A., Ocké, M. C., Zielhuis,G. A., Goorhuis-Brouwer, S. M., van der Biezen, J. J., Kuijpers-Jagtman, A. N. and SteegersTheunissen, R. P. (2003). Does the interaction between maternal folate intake and the methylenetetrahydrofolate reductase polymorphisms affect the risk of cleft lip with or without cleft palate? American Journal of Epidemiology, 157(7), 583- 591. doi:10.1093/aje/kwg005

Weinberg, C. (1999).Methods for detection of parent-oforigin effects in genetic studies of case- parents triads. American Journal of Human Genetics, 65(1), 229-235. doi:10.1086/302466

Zucchero, T. M., Cooper, M. E., Maher, B. S., Daack-Hirsch, S., Nepomuceno, B., Ribeirol Aprau, D., . . . and Murray, J. (2004). Interferon regulatory factor 6 (IRF6) gene variants and the risk of isolated cleft lip or palate. The New England Journal of Medicine, 351(8), 769780. doi:10.1056/NEJMoa032909 